\title{
PERAN PEMERINTAH DESA DALAM MENGANTISIPASI BONUS DEMOGRAFI (PERNIKAHAN DINI) TERHADAP KAUM MILENIAL
}

\section{The Role of Village Governments in Anticipating the Bonus Demography (Early Marriage) Against Millenials}

\author{
Mohammad Saleh, Abdul Khair, Sarkawi, Kafrawi \\ Program Studi Ilmu Hukum Universitas Mataram \\ Jalan Majapahit No 62, Kota Mataram Provinsi NTB \\ *Alamat Korespondensi : msalehfhunram@gmail.com
}

(Tanggal Submission: 4 November 2020, Tanggal Accepted: 28 Desember 2020)

\begin{abstract}
ABSTRAK
Perkawinan bagi manusia merupakan hal yang penting, karena dengan perkawinan seseorang akan memperoleh keseimbangan hidup baik secara psikologis, sosial, maupun biologis. Seseorang yang melangsungkan perkawinan, maka dengan sendirinya semua kebutuhan biologisnya bisa terpenuhi. kematangan emosi merupakan aspek yang sangat penting untuk menjaga kelangsungan perkawinan. Keberhasilan suatu rumah tangga banyak ditentukan oleh kematangan emosi baik suami maupun istri. Batas usia dalam melaksanakan perkawinan sangatlah penting karena didalam perkawinan menghendaki kematangan psikologis. Usia perkawinan yang terlalu muda dapat mengakibatkan meningkatnya kasus perceraian karena kurangnya kesadaran untuk bertanggung jawab dalam kehidupan berumah tangga. Perkawinan yang sukses sering ditandai dengan kesiapan memikul tanggung jawab. Tujuan Pengabdian Untuk melaksanakan Tri dharma Perguruan Tinggi, salah satunya yaitu pengabdian kepada masyarakat. Memberikan pemahaman kepada kaum milenial terhadap dampak pernikahan dini. Memberikan pelatihan dan edukasi agar kaum melineal memeiliki nilai tambah dan terhidar dari persoalaan pernikahan dini. Metode yang digunakan diantaranya adalah: Ceramah, diskusi dan konsultasi hukum. Hasil: pemahaman masyarakat terhadap resiko perkawinan usia dini masih rendah, hal ini dikarenakan banyak faktor, diantaranya faktor ekonomi, sosal budaya masyarakat dan pendidikan. kesimpulan: dengan adanya program kampung KB, diharapkan dapat menekan laju bonus demografi di desa serta dapat meningkatkan kesejahteraan hidup masyarakat desa.
\end{abstract}

Kata kunci: Pernikahan, Bawah Umur.

\section{PENDAHULUAN}

Manusia dalam proses perkembangannya membutuhkan pasangan hidup yang dapat memberikan keturunan untuk meneruskan jenisnya. Perkawinan sebagai jalan yang bias ditempuh oleh manusia untuk membentuk suatu keluarga atau rumah tangga bahagia yang berdasarkan Ketuhanan Yang Maha Esa. Hal ini dimaksudkan bahwa perkawinan itu dilaksanakan sekali seumur hidup dan tidak berakhir begitu saja. 
Perkawinan bagi manusia merupakan hal yang penting, karena dengan perkawinan seseorang akan memperoleh keseimbangan hidup baik secara psikologis, sosial, maupun biologis. Seseorang yang melangsungkan perkawinan, maka dengan sendirinya semua kebutuhan biologisnya bisa terpenuhi. Kematangan emosi merupakan aspek yang sangat penting untuk menjaga kelangsungan perkawinan. Keberhasilan suatu rumah tangga banyak ditentukan oleh kematangan emosi baik suami maupun istri.

Batas usia dalam melaksanakan perkawinan sangatlah penting karena didalam perkawinan menghendaki kematangan psikologis. Usia perkawinan yang terlalu muda dapat mengakibatkan meningkatnya kasus perceraian karena kurangnya kesadaran untuk bertanggung jawab dalam kehidupan berumah tangga. Perkawinan yang sukses sering ditandai dengan kesiapan memikul tanggung jawab.

Keharmonisan rumah tangga merupakan impian mayoritas orang yang melakukan pernikahan, karena jika dalam rumah tidak terbentuk keluarga yang harmonis keretakan rumah tangga akan mudah terjadi, untuk menciptakan rumah tangga yang harmonis di dalam islam sendiri sudah mengajarkan untuk bisa mencapai keluarga yang harmonis, tujuan perkawianan menurut agama islam ialah untuk memenuhi petunjuk agama dalam rangka mendirikan keluarga yang harmonis, sejahtera dan bahagia. Harmonis dalam menggunakan hak dan kewajiban anggota keluarga, sejahtera artinya menciptakan ketenangan lahir dan batin disebabkan terpenuhinya keperluan hidup lahir dan batin, sehingga timbulah kebahagiaan yakni kasih sayang antar anggota keluarga (Ghozali, 2003).

Menurut subekti pernikahan adalah pertalian yang sah antara laki- laki dan perempuan untuk waktu yang lama. Pernikahan adalah salah satu perintah peristiwa yang sangat penting dalam kehidupan masyarakat, sebab pernikahan tidak hanya menyakut pria dan wanita calon mempelai saja, teteapi juga kedua orang tua kedus belah pihak, dan saudara-saudaranya bahkan keluarga merka masing-masing (Subekti 1985).

Pernikahan dini diartikan merupakan instituisi agung untuk mengikat dua insan lawan jenis yang masih remaja dalam satu ikatan keluarga. Ada beberapa factor penyebab terjadinya pernikahan dini, yaitu factor pribadi dan factor keluarga. Dari factor pribadi remaja adalah karena ingin menghindari dosa (seks bebas), dan ada juga yang karena "kecelakaan". Sedangkan dari factor keluarga adalah karena paksaan dari orang tua (Luthfiyati, 2008). Berdasarkan latar belakang di atas, maka rumusan maslah yang dapat diangkat dianataranya adalah: Bagaimana Peran Pemerintah Desa Dalam Mengantisipasi Bonus Demografi (Pernikahan Dini) Terhadap Kaum Milenial Di Desa Banteng Keselet Kabupaten Lombok Tengah.

\section{METODE}

Penyuluhan hukum dilakukan dengan metode : Ceramah yaitu Peran Pemerintah Desa Dalam Mengantisipasi Bonus Demografi Terhadap Kaum Milenial Terhadap Pernikahan Dini. Diskusi yaitu dengan membuka kesempatan tanya jawab kepada peserta dengan Tim Penyuluh mengenai materi yang disampaikan. Adanya metode diskusi diharapkan dapat lebih membuka wawasan dan meningkatkan pemahaman peserta penyuluhan mengenai materi yang elah disampaikan oleh Tim penyuluh. Konsultasi Hukum yaitu dengan memberikan kesempatan kepada peserta untuk mengajukan sejumlah permasalahan hukum berkaitan dengan pelaksanaan otonomi desa kepada tim penyuluh. Konsultasi hukum dilaksanakan setelah acara penyampaian materi dan diskusi. Penyuluhan hukum dilaksankan di Desa 
Banteng Keselet Kabupaten Lombok Tengah. Adapun Khalayak sasaran dari kegiatan ini adalah: Kepala desa beserta staf desalainnya Ketua BPD dan anggota BPD, Pemuka Agama,Pemuka Masyarakat serta tokoh-tokoh Pemuda.

\section{HASIL DAN PEMBAHASAN}

Secara etimologi kata nikah (kawin) mempunyai beberapa arti yaitu berkumpul, bersatu, bersetubuh, dan akad. Adapun kata nikah secara terminology, menurut imam syafi"i nikah yaitu akad yang dennganya menjadikan halal hubungan seksual antara pria dengan wanita . menurut imam Hanafi ni kah yaitu akad yang menjadikan halal hubungan seksual sebagais uami antara seorang pria dengan wanita. Menurut imam malik nikah adalah akad yang yang mengandung ketentuan hukum semata-mata untuk membolehkan wathi' (bersetubuh),bersenang-senang, dan menikmati apa yang ada dalam diri wanita ang boleh menikah denganya . menurut imam hanafi nikah adalah akad dengan menggunkan lafaz nikah atau tazwij untuk membolehkan manfaat, bersenang-senang dengan wanita

Menurut subekti pernikahan adalah pertalian yang sah antara laki- laki dan perempuan untuk waktu yang lama. Pernikahan adalah salah satu perintah peristiwa yang sangat penting dalam kehidupan masyarakat, sebab pernikahan tidak hanya menyakut pria dan wanita calon mempelai saja, teteapi juga kedua orang tua kedus belah pihak, dan saudara-saudaranya bahkan keluarga merka masing-masing.

Pernikahan dini adalah pernikahan di bawah usia yang seharusnya belum siap untuk melaksanakan pernikahan. Sehinga seharusnya pernikahan dilakukan pada saat remaja sudah memasuki usia dewasa, karena ketidaksiapan dalam pernikahan berdampak pada kehidupan berumah tangga. Kurangnya pendidikan dapat memicu terjadinya pernikahan usia dini, karena tanpa dibekali pendidikan yang cukup remaja tidak bisa berpikir panjang dalam menentukan pilihan sehingga memilih untuk cepat-cepat menikah.

Pernikahan dini di dalam undangundang tidak ditemukan istilah penegertian penikahan dini atau pernikahan di bawah umur, istilah ini muncul setelah adanya undangundang No 1 Tahun 1974 yang mengatur pernikahan di dalam undang undang-undang tersebut dalam pasal 7 ayat 1 diterangkang bahwa perkawinan hanya di izinkan jika pihak pria sudah 19 (Sembilan belas) tahun dan pihak wanita 16 (enam belas) tahun. Jadi menurut undang-undang dikatakan pernikahan dini apabila salah atu atau kedua calon mempelai berusia di bawah 19 atau 16 tahun, pernikahan di bawah umur ini di bolehkan oleh Negara dengan syarat dan ketentuan tertentu.pernikahan usia muda atau pernikahan di bawah umur dapat diartikan menikah dengan usia yang masih sangat muda yaitu sangat di awal waktu tertentu, dalam artian masih dalam kadaan kehidupanya yang belum mapan secara sikis dan psikologi.

Bahwa dalam masyarakat yang majemuk yang tingkat pendidikanya belum memadai, terutama masyarakat pedesaan, tidak heran kalau sebagian besar masyarakat masih berpegang pada tradisi, kebiasaan lama oleh leluhur masih kental dipegangnya anatara lain ingin cepat mengawinkan anaknya. Dan di dalam undang-undang sendiri juga tidak menutup total celahuntuk melangsungkan pernikahan akan tetapi undang-undang membuka peluang terjadinya pernikahan di bawah umur melalui proses dispensasi nikah oleh pengadilan, dizinkan atau tidaknya tergantung pada hati nurani hakim yang memeriksa dan memutus di pengadilan. Begitu pula dengan fiqih munakahat secara normati membolehkan adanya pernikahan dini meskipun demikian haruslah 
mempertimbangkan maslahat dan mudhorotnya.

Indonesia akan memasuki fenomena bonus demografi. Yakni Indonesia mengalami peningkatan jumlah penduduk usiaproduktif secarasignifikan. Hal ini terjadi karena keberhasilan program KeluargaBerencana (KB). Melalui keberhasilan program Keluarga Berencana merubah strukturumur penduduk yang ditandai dengan menurunnya rasio ketergantungan (dependency ratio) penduduk non-usiakerja (0-14 tahun dan diatas 65 tahun) terhadap penduduk usia kerja (15-64 tahun). Bonus demografi merupakan kondisi di mana populasi usia produktif lebih banyak dari usia nonproduktif. Indonesia sendiridiprediksiakanmengalamipuncak bonus demografi pada 2030 mendatang.

Menghadapi bonus demografi kepada generasimuda atau yang biasa disebut milenial saat ini memang banyak diselimuti oleh masalah, diantaranya adalah masalah kecemasan dan depresi, di dalam penelitian tersebut menjelaskan bahwa hubungan antara media sosial dan gejala depresi lebih kuat di remaja perempuan disbanding laki-laki. Untuk remaja perempuan, semakin lama memakai media social maka semakin meningkat juga gejala depresinya.

Gejala depresi ini menjadi terjadi menurut para penelitian bahwa akses smartphone dan penurunan waktu tidur yang sesuai, mungkin merupakan factor unik yang banyak mempengaruhi Gen $Z$ dari pada millennial. Terlebih lagi, para peneliti menemukan bahwa remaja dan orang-orang di usiaawal 20-an, semakin berisiko mengalami masalah kesehatan mental yang parah.

Dalam perdebatan akademis, muncul sebuah kritik dari Drilling (2013) tentang upaya mencapai keharmonisan tiga dimensi besar ekonomi, sosial, dan lingkungan- dalam kota berkelanjutan. la menyebut bahwa dalam konteks pembangunan perkotaan yang berkelanjutan, terdapat tiga posisi yang sangat menarik yaitu pertama, tujuan ekologis, sosial, dan ekonomi tidak dapat digabungkan karena tujuan ekonomi selalu menargetkan pertumbuhan, dan tujuan ekologi selalu menargetkan batas; kedua, pilihan untuk memenuhi tujuan perlindungan lingkungan (perlindungan ekosfer), stabilitas ekonomi (pembangunan ekonomi terus stabil), dan keadilan sosial (peluang kelangsungan hidup yang sama) secara bersamaan dan dengan nilai yang sama memungkinkan untuk menjadikannya sebagai strategi tindakan yang berorientasi pada masa depan; dan ketiga, pendekatan keberlanjutan adalah strategi pengamanan dominasi modern. Selain itu ini dianggap merupakan bagian dari konsep hegemoni baru karena tidak memperhitungkan hubungan kekuasaan antar subjek yang merupakan dasar dari kerusakan lingkungan dan munculnya kemiskinan. Dalam halini, keberlanjutan tidak banyak member perubahan dari konsep sebelumnya.

Pembangunan berkelanjutan dimaknai sebagai "perkembangan atau pertumbuhan yang memenuhi kebutuhan masa kini tanpa mengorbankan kemampuan generasi mendatang untuk memenuhi kebutuhan merekasendiri". Definisi lain tentang pembangunan berkelanjutan yaitu proses dinamis yang menghubungkan keprihatinan lokal dan global, serta menghubungkan isu-isu sosial, ekonomi, dan ekologi lokal, untuk memenuhi kebutuhan generasi sekarang dan masa depan. Sementara itu, Rochecouste dan Leonie (2014) menegaskan bahwa komposisi utama dari kota berkelanjutan adalah people and place. Apabila kita memulai dengan teknologi, maka yang akan kita peroleh hanya teknologi. Apabila kita memulai dengan design, maka yang akan kita peroleh hanyalah rancangan semata. Akan tetapi apabila kita memulainya dengan people dan place dan di mana kita saat ini (konteks kekinian), makakita 
akan mampu membuat perubahan nyata dan mengubah kehidupan orang lain.

Höjer, Gullberg, and Pettersson menyatakan bahwa ada risiko yang sangat nyata melekat dalam pertumbuhan perkotaan dan perluasan gaya hidup urban, yaitu bahwa dari penggunaan sumberdaya yang terus meningkat dan beban lingkungan jauh melampaui apa yang dikelola oleh alam. Kebalikan yang diinginkan adalah sebuah kota ekologis yang berkelanjutan. Dalam penelitian ini, mereka mendefinisikan kota sebagai tempat dimana para penghuninya bias hidup dengan baik dengan cara mempertahankan kelestarian dan mencagah kehancuran sumberdaya kolektif serta meninggalkan sumberdaya tersebutu ntuk generasi yang akan dating tanpa perubahan nyata yang lebih buruk. Pembangunan perkotaan yang berkelanjutan juga mengandaikan bahwa gaya hidup perkotaan tetap diterima secara sosial dan finansial yang memuaskan. Namun, penekanan utama dalam pemahaman mereka tentang pembangunan perkotaan yang berkelanjutan adalah pada pemanfaatan sumber daya rumah tangga dan bagaimana struktur perkotaan, lembaga, dan pola hidup dapat dimanfaatkan untuk berkolaborasi mengelola pemanfaatan sumber daya dalam batas yang dapat diterima (Hojer et al., 2011).

Pembangunan berkelanjutan ini diartikan sebagai perubahan yaitu mampu mensejahterakan kehidupan masyarakat yang tentunya agar lebih baik dari sebelumnya, dan pembagunan diartikan sebagai pertumbuhan adalah suatu kemampuan untuk meningkatkan masyarakat agar semakin berkembang, hal ini telah mutlak terjadi dari segi kulitatif maupun kuantitatif yang harus mengalami peningkatan dalam pertumbuhan.

\section{KESIMPULAN}

$\begin{array}{clc}\text { Dengan dilakukannya } & \text { penyuluhan } \\ \text { hukum ini, } & \text { diharapakn memberikan }\end{array}$

pemahaman kepada kaum milenial terhadap dampak pernikahan dini, dapat menekann bonus demografi di desa, meningkatnya kualitas hidup dan ekonomi serta dapat memberikan pelatihan dan edukasi agar kaum melineal memeiliki nilai tambah dan terhidar dari persoalaan pernikahan dini

\section{UCAPAN TERIMAKSIH}

Dalam kesempatan ini, tim penyuluhan hukum menyampikan ucapan terimakasih kepada Rektor Universitas Mataram atas bantuan dana pengandian. Tidak lupa tim sampaikan ucapan terimakasih kepada Dekan Fakulktas Hukum Unram atas segala bantuan dalam penerbitan SK Penyuluh, Kepala desa tempat kegiatan penyuluhan dilaksanak dan semua peserta yang terlibat untuk menyukseskan kegiatan penyuluhan ini.

\section{DAFTAR PUSTAKA}

Drilling, M. (2013). Planning Sustainable Cities: Why Environmental Policy Needs Social Policy. Isidor Wallimann (ed.). Environmental Policy is Social Policy Social Policy is Environmental Policy: Toward Sustainability Policy, New York: Springer.

Ghozali, A.R. (2003). Fiqih Munakahat HIm 22. Jakarta : Kencana Prenada Media.

Hassan, A.M., \& Lee, H. (2014). "The paradox of the sustainable city: definitions and examples", Online journal. Accessed on 9November 2019.

Höjer., Mattias., Gullberg, A., \& Pettersson, A. (2011). Images of the Future City: Time and Space for Sustainable Development, Dordrecht: Springer

Luthfiyati, D. (2008). Metodologi Penelitian Kesehatan. Jakarta : RinekaCipta.

Rochecouste, G. and Leonie J.P. (2014). Delivering Resilient, Sustainable Cities is All about People and Place. Leonie J. Pearson, Peter W. Newton, and Peter 
Roberts (eds.). resilient Sustainable Cities: A Future, New York: Routledge.
Subekti. (1985). Pokok-Pokok Hukum Perdata HIm 234. Jakarta: PT Intermasa. 